\title{
Poverty and Women Status among the Fishers Community in Contemporary Era
}

\author{
Waskito Widi Wardojo \\ History Program, Faculty of Humanities, Sebelas Maret University, Indonesia \\ Doctoral Student of History, Faculty of Humanities, Universitas Diponegoro, Indonesia
}

\begin{abstract}
There is a significant change in how people see fishers these days, as previously this particular profession was tightly related to poverty, and had the tendency to be subsistence. This includes the role of female fishers. Now they do not necessarily have to stay at home waiting for the return of their husband from fishing, but actually, participate in the act of fishing on the sea along with their husband. Today, women already acknowledged by the government. There is even a success story of female fishers

Received:

April 29, 2019

\section{Accepted:}

July 16, 2019

Corresponding Author:

waskitowidiwardoyo@gmail.com in Juwana, Pati, Central Java. In the eighties, fishers in that area lived in poverty. Now they thrive and leading life in prosperity. Does this mean poverty is not so tightly related to the fishers anymore? How fishers of Juwana answer the question? How is the fate of female fishers now that their status is already acknowledged as a legit profession?
\end{abstract}

Keywords: Poverty; Women; Fishers; Social Status.

\section{Introduction}

In the eighties, a book by Mubyarto often became reference for the life of fishers living in the norther coast area (Mubyarto et al. 1984). The study done in two villages only provides a stronger proof. The majority of the fishers there are subsistent, in line with concept of subsistence farming from James Scott. In the book, fishers are described as a class lower than farmers, which was also categorized as poor class. One of the factors that caused poverty in Bulu and Ujung Batu village in Jepara, is the abundance of fish resource. This causes many fishers came from outside of Jepara area. This causes most of the yielded by fishers from outside of Jepara. The poverty factors in the two villages is also affected by the low education (even though it is not a determinant factor, because village with the same level of education could thrive and achieve different level of prosperity). Data from Bulu shows that there are 1,783 people, most of the population there, do not graduate Elementary School, and graduate from Junior High, while there are only eight people graduated from college. Economic history shows that, the peak of prosperity level happened in 1960's, when prawn, previously considered as daily staple, turned into commodity of high value because the price sky-rocketed. The effect, fishing equipment were upgraded, trawl boats could be operated around Java island. However, the commodities gradually decreased day by day, and the prawn fever only lasted around four years $(1972$ - 1976). Post the prawn fever, the people of the village sink lower in poverty. The arrival of purse seine boat with attached motor $50 \mathrm{PK}$ still could not yield better results from their fishing. The fishers of Bulu ended up becoming workers for those purse seine boats. Regarding the profession profile, there are 461 people in productive age registered, 350 of them being fishers (majority), 31 people are civil servant/ defence force, the population become Civil Servant, rice field worker, industrial worker, merchant, and retiree.

The interesting part is, when Mubyarto describes the working portion in Bulu village into two group, based on age and gender. The head of the family is male, and the family member is the wife and the children. In order to strengthen the family's economy, the wife usually help meeting ends by selling fish, either at the market as fishmonger, or selling the goods by batches. Other than selling fish, there are other professions for the wives, such as becoming per-day worker, or cleaning prawn 
from the merchants there. The boys and girls, while their parents are working to help steady the family's economy, become alang-alang, a term for a group of kids following fishers, trying to get fish without having to buy it. It's either by waiting for any fish to fall off from the fishers's carriage, or stealing the fish from it. While the girls, also become rebyek. It is a term for people coming to fishers's boat to buy their yield before they sell it to the fish market. This research, it is found that rebyek does exist, though the local claimed that those come from the neighboring village, not native from Bulu. Usually, the more beautiful the girl who do the bargain, the better the price will be. This is due to the fact that the bid will later be followed up by certain sexual act.

The research revealed the result of interview that categorized fishers based on various situations: tenacious, successful, owner, and former fishers (Béné and Friend 2011). The conclusion of the book is defined into two; substantive and theoretical conclusions. Substantive conclusion deliver the idea that fisher is a very tough job. Only a very simple requirement is needed to be a fisher, and one could learn from their parents since they were little. When the parents have better financial condition, they will send their children to the highest level of education so they do not have to be fishers. From all the examined cases, most of them could not afford the luxury, and become fishers from generation to generation. Thus, fishers and poverty becomes a predestined fate to each other, a unity in a networking structure that is caused by the power of circumstances. To put it simply, rich and very rich fishers are real, and so are poor fishers and poor laborers. The poor group usually consist of people aged more than 40, where they have lost their chance to improve their economy and social level. On the other hand, laboring is the job they pushed themselves to do before or when they are not as strong for heavy work. Among the people in their productive age, being a fisher is profession in majority. This group tends to name themselves as poor group with the tendency on dramatizing their poverty for the lots of struggle in their work and life. They complain on the little income they get that is barely enough or even too little for their daily needs spending. This drives the member of the fishers family, their children or wife, to find work in order to help the family's economy. This group's concern becomes their basic opinion on the concept of prosperity, welfare and happiness. Family encouragement then does not only caused by the lack of income from the head of the family.

For the bottom layer group of people from the two villages being observed, it is found that it is true that the people's need on helping each other and mutual help stand out even more compared to the middle and top layer groups. Sambatan is included in this concept. Sambatan is mutual help done to build house by asking the neighbor's help without paying them.

Theoretical conclusion, on the other hand, explains Durkheim analysis that emphasize the fact that group's attitude could be predicted based on which personal attitude that cannot be predicted. This statement pioneered the idea on how calculation knowledge could change reality. This statement, however, is denied by Douglas who believed that statistic could not be use alone or with value phase, let alone to change the reality. It is not a social reality or social reality, but an interpretation of the fact or reality. This research also explains the critic to various development programs, including Revolusi Hijau that shows the important meaning of qualitative data, especially the local and native views on life. Anthropology approach on social analysis is one of the methodologies being used for observing various ongoing development processes.

Learning from observing fishers of Bulu and Ujung Batu village, other experiences with different people situation and condition could also be observed.This research only compares in general. The measured parameter should have parallel measurement standard from the same period of time. Two locations, Banda village of Juwana Pati sub-district, and Bawean village in East Java, have interesting phenomena. Why the two locations? The reason is both have the same background with the two villages in Jepara. If a historic comparative to be done, it should be compared within the same period of time. This for example, if the research is to be done on people of Bulu Jepara, how was the people's condition in Bendar dan Bawean at the same period of time, exactly on the late seventieth to the early eightieth? As this research is sociological, not historical, it does not strictly explain the methodology. Hopefully, this research could begin greater research in the future, despite the limited time available for the arrangement. Just like retail, fishers historiography could 
be served in depth and in detail to obtain wider description, despite the object being written in micro level. This research depicts merely the profile of successful fishers in a particular village that is shaped by the society's expectation of working for prosperity, not for poverty. Being poor is not anyone's purpose, if cannot be said as a given, and fisher is not a profession correlated with poverty.

The researcher should observe and learn more about Bendar Juwana Pati village, as it is known as a successful fishers village that it is now a boat seller village. They have houses as big as village hall, sometimes even with swimming pools in its yard. Literary search result shows that this small village in Pati is unique in its own way. Is this because of their bravery to come out of their profession zone as only fishers who spends most of his time in the sea? Actually, it depends on the season when they go to the sea; if it is a rainy season, will they spend most of their time at home, in the fields as farm laborer, so that the wife becomes the backbone of the family just like how it happens in the neighboring village?

\section{Social Economic Status}

The background of Ujung Batu village, which is populated by 1,974 people at that time? Regarding the educational profile, there seems to be no significant difference with Bulu. The poverty of fishers as depicted by Mubyarto, seems to be in line with the theory of structural poverty which was becoming a hot topic among the intellectuals. Mubyarto, even quite successfully, has made the structural poverty theory into a reference for the government in the poverty alleviation policy making process. In the time of New Order, various development policies for poverty alleviation had emerged. One of those was the fishers empowerment, which was found to be quite apprehensive even at that time.

This includes role factor of KUD (Village Unit Cooperatives). These units, established to help fishers grow their business, turned out to be failing its purpose. The units should help fishers or laborers to provide loans for fishing equipment, such as fishing nets or motor engines. However, the program failed in providing the service, for the loans fill the pocket of the boat owner instead. "The rich gets more rich and the poor gets poorer" is a complain heard among the fishers. The dissatisfaction grew bigger as they watched the units and market management members with less working year (approximately two years) could afford themselves new house or new boat. The leader of the units was not chosen by election in formal meeting of the unit members. This strengthened the rumor that the chosen leader was someone with network or direct relationship with important officials. The units then had been widely assumed to be a company of some people who cultivated it since then. No single loan was intended for Bulu's fishers. This condition makes rooms for illegal loans or shady bank, even though laborer and fishers have to pay the high interest of $15 \%$ to $30 \%$ for each month to take it. People who take loans from them usually use the money to buy house equipment. When the economic pressure gets high, especially in rainy season, many of them resell the equipment they just bought or put them in pawn for half its price.

Social and economic condition of Bendar village in around 1970 to 1980 was similar with the two observed villages. The condition was that those villages have low education level, full of cramped and slum houses, where most of the people are structurally poor. However, after the revitalization of Juwana river by the government, boats could make use of the river to develop the village's economy. Gradually, fisherman and skipper developed and advanced that fisherman becomes boat maker, masm. A research by Suhardi, entitled Perkembangan Masyarakat Nelayan Desa Bendar Kecamatan Juwana Pati 1969-1983 that Bendar fishers consist of three groups; The first is that skipper fisherman is the owner of the big boat of $15 \times 6$ meters. The second, the fisherman alone is the owner or the tenant of temple boat of $7 \times 3$ meters. Next, the fishers laborer is those who has no boat but $s$ worker of labor in the fishing process (Suhardi). Those three groups have different life pattern in its relation with the family. The wife would take care of the domestic needs for the fishers who is often stays for days in the sea. Meanwhile, the fisherman of the Juwana river and sea has shorter working hour, which is around one to half a day. The head of the family is a function that is clear for skipper group, as they have more time with the family, even have their 
own subordinates to take care of the operational process. It is also described in the research that skipper usually hire laborers as a worker for the boat building. The helper for the fishing and boat building usually includes the adult cousin or nephew of the skipper into the team. Suhardi refer to James Scott statement on returning the favor, in order to describe relationship between skipper and fisherman. This is for the fact that fisherman often generously give a hand to the people or other fisherman that they continue this pattern. They accept the favor and return it by being grateful to them and become submissive to the order. This causes reinforcement, morally, from the existing social stratification. By giving a hand to the laborers and fisherman, the skippers want to make a working bond that stops them from working freely. For the price of fish is in the skipper's hand, laborer and fisherman has always been in the bottom condition with their economic problem. In the same Bendar research, people of the village have known them as wong mbelah, a fisherman who uses rower. This term refers to the fisherman going to the sea. This term has disappeared gradually among Bendar or other coastal people. Fisherman itself is a term that was known after the fisherman day was set.

Observing data starting from 1969 to 1983, Suhardi focused on two things: First, the bonding development between skippers and laborers; second, motorization role to the fisherman people and credit given by the government in Bendar village. Suhardi concluded that fisherman has strong motivation to keep their job, despite of their limited education level. Even with the presence of new technology, the fishers's dependency to the skipper could not be erased yet. From the fisherman's perspective, they feel obliged to return the favor. It brings skipper to the honorable position in the village, as a figure. To their own accord, skippers also keep the dependency, in order to stabilize fisherman's working bond and ethic. Other conclusion is that the presence of new technology in Bendar village has brought progress in the sector of fisheries. Fishers can update or equip their fishing tools in order to increase their income. Motorization has cut the needs of laborer numbers in the process. Laborer is now a carpenter or a transporter worker who move fish to the auction.

Also, it is concluded that Bendar village people have adaptive attitude towards the local government policy. This could be one of the determining factors for the success of Bendar fishers. The path to success is widely open also thanks to the government policies that help the people's boat building activities. Separate research should surely be conducted to answer questions regarding the village's success factor.

A fisherman who is considered as successful, with a story published in social media is Haji Sumarno, a son of the village who was born in 1969 (Saktiya 2016). Sumarno, now a boat owner, leads a successful life by starting small with his convensional row boat with sails. Sumarno was able to afford himself motor machine, thanks to his frugal attitude and saving habit. These days, he has six big boats, shipyard, ice factory and rural bank in Pati. His income is estimated at 3 billion per month from all of his business combined. All of that without great education level; he stopped in the middle grade at elementary school. At that time, most of the kids were interested in the sea. He followed his friends and went fishing to help his parents' economy "I can't bear seeing my father suffer alone. For the sake of their children, he had to stay in a small boat floating alone in the day and even at night with the heavy rain, high waves and all. "So is the story of his success be like a fairy tale turned to reality. Seeing the facts, local government decided to give the village special attention. They monitor the development, it become an icon of the richest fisherman village in the country, with great income between 25 to 100 million for each catch. Around 500 small and big boats are in their possession.

Bawean island in East Java has its own success story, just like Sumarno. A number of social scholars have conducted their research from different aspects in the area, namely Drajat Tri Kartono, Addin Kurnia, and Patrick Guinness. Drajat Tri Kartono's research in 2004 used social economy approach in observing adaptation skill of social economy institutions among the social changes. It is known that among Bawean people, the profession has shifted from fisherman to immigrant; in Malaysia, for example, this immigrant community was found. This research focuses on the changes and adjustment of the social-economy institutions, rather than the symptom of labor 
structural change. Drajat points on two main ideas. The first is the social and economy life of Bawean people that depends on the income from their immigration. Next, is it is influence to the social-economy life development of the people. The result showed that the international economy life of Bawean people (represented by working abroad in Malaysia) is a bilateral result of changes in the knowledge, attitude, local social-economy institution and adaptation to the international economic life system in Malaysia. Those changes have influenced the economy development of the international labor migrant and also impacted the life structure in the place of origin. This signifies two-way relationship and transformation process of the international economy and of the local people. All proves the idea that not only that local people has changed and moved along the flow of the global stream (Global Fluids), but also they made and effort to shape their identity and competitiveness in the international economy system. Thus, Bawean people now has more than enough income to stand in their feet, even more than what the fisherman could have years before. From various researches conducted in Jepara, Pati and Bawean, the result shows that fisherman, in its pure form, is fighting back their condition that pushed them close to poverty, rather than fisherman and poverty as a predetermined fate to each other.

\section{Fisherman Working Organization}

There are three main aspects in the fisherman chain of job, starting from fish catching, marketing, and production. To be lined up with physical work and non-physical work of men and women, these three aspects are dominantly done by man. Further study could surely observe deeper on the work division based on sex.

For small scale fisherman people, it is important to be aware that the role of man and women at work is balanced. In other areas, however, women tends to have bigger work portion than man. Other than the limited available fishing equipment which depend on the season and sea breeze, fishers habitually stop going to the sea on September to March each year, when the waves are mounting and dangerous. At that time, as mentioned in Drajat Tri Kartono's research on Tuban fishers, their wives play role as the head of the family when their husbands went fishing. It is also found that some of them work as prostitutes. From this point, women fisherman has even three roles: domestic, production and community management, all at the same time. They take care of almost all of the work in the land in order to fulfil daily needs: food, clothing and housing.

Researches on elderly fisherman women, for example as described by Triratnawati (2012). alang-alang started existing since the establishment of fish market in the northern coastal area of Java. At first, they consisted of school grader and mothers asking for fish for their personal daily needs. After 1970, there was a change in alang-alang as profession. Children used to work to help their parents fulfilling daily needs as alang-alang, but now poor elderly women with no husband (divorced or passed away) with not much strength to do the selling, alang-alang become their purpose in life. The Javanese culture that used to put elderly women as a figure with certain power is not what they have in the fisherman culture. Being entangled with poverty, a fisherman's family could not take care of their mother. Thus, poverty pushed alang-alang as an alternative for elderly women to live independently. Alang-alang has been understood as asking for and stealing fish from the boat carriage, making it hard for the crew to transport and further the process. Actually, senior women become active alang-alang with various background as their reasons.

Cultural characteristics of small-scale fishing communities describe senior women's role, social organization, and work division. Balanced social role expectation for man, women, children, adult and older people is also mentioned in the research. Normative class on gender and age is generally emerged from two different factors that is interrelated and is able to change dynamically. The first factor is the needs of practical requirement on various fishing activities. The second is the bigger culture that determines things, including what is related to normative gender and age class role.

In general, social norms for most of small scale fisherman village in the world are determined to have man as the main producer, especially in production activities that happen in the sea. Women, on the other hand, is expected to fulfil a double role: first, as the mainstay for the 
household and their children, and the second as the mainstay for fish production, marketing and distribution. Other expectation is seen regarding normative role for son and daughter, and for elderly people. Therefore, sons and adult men are often expected to do line of work that includes fishing in the shore, working with their brother, while daughters and adult women are expected to do tasks around the house, as well as working with their sisters.

While it is normative in most of small scaled fisherman people, these patterns are various and there are exceptions in different culture area. For example, in most of Asia's small scaled fishers, women also work in the sea, but not for some Moslem women people. They are not allowed to be involved directly in fishing activities.

Other typical social norms emphasize the importance of family members being supportive to each other, even when they are doing different works. In most of developed country, for example, household can be set as "household company" that vertically combined fishing production, processing, marketing, and distribution activity. Usually, household members are expected to be able to work cooperatively for a greater effect on the result, as well as to work cooperatively with other household, especially those who are pregnant. This cooperative working is to gain mutual benefit for everyone, including supportive acts on people's important rituals and other events.

\section{Women's Double Role in Small-scaled Fishers Community}

Usually, women is still expected to play double, especially for some fisherman people of a smallscale, as the mainstay for the household, children, and as for the fish production, marketing and distribution. This is why women from the fisherman family usually take some of her husband's catch for all the family to eat, as well as to exchange it with other daily needs, for example a knife as an exchange with fish and or vegetables. Moreover, it is natural to see a women performing in other economy relations in the society, for example, getting loans from local food seller in order to maintain the family's economic stability.

Women in the community generally have even wider and complex social networking compared to their men who spend most of their time away from the society. Double role played by women of this community emphasize their fundamental interest in their social and economic condition; particularly, their crucial interest in maintaining the society as a whole. This excellence brings a sense of dependency, economic autonomy, and social and economy influence to the women who are involved in the fishery than women who are not involved. This is also the reason why those women stand out more. Furthermore, the time they spend in the community allow them to expand their network while their husbands are going fishing. All those networks help them to facilitate fishing result in terms of marketing and distribution activities.

Matrifocal household could also be seen in some of this small-scaled fishers community. Matrifocal household is a household with mother as the head of the family and children as the member. This family usually consist of adult women, children, her mother, and sometimes her sister with her children. This household organization model usually happen as an adaptive response against the long empty spot of the adult man while they go to the sea and process the fishery activities. This situation leads to women managing both the daily household needs and society's business, all of the year. Adult women of matrifocal family usually have stronger personal economic power and autonomy, compared to those of non-matrifocal ones.

Women in the small fisherman community also works as the main seafood producer, where she works in the protected water area near her children and her home. The final product is basically an essential needs supplied for the family.

Women are mostly found to be working in the processing activities than man. The activities provide them cash essentials to their household care taking. Sometimes, they make more than the husband, means better income stability and continuity than their husband can make from the fishing activities. This processing work may not be harmful, like fishing in the offshore. Illness or work accident, or any other medical problems are considered common. 
Often times, women is an important contributor to the other fishery activities, including marketing and distribution, working with the client's network, broker, and planning a journey to the far away market. Their absence in processing, producing, marketing and distributing process makes it hard for their family members, especially their children. Women as an important contributor is also significant in other fishery activities. For example, what can be their main responsibility is to maintain communication with the husband when they are away, to schedule boat maintenance when its back, to buy new fishing tools and also to remind prospective buyer on the fishing haul.

This shows that some of the processing, marketing and distribution activities executed by women are one the most important economic contributions (Béné 2003). As the society's convention on the role of work and gender that is dynamically changing, women let herself contribute in bigger part, as well as being involved the primary production process. All changes in this traditional gender role could lead to discomfort to some community members. Some may put preventing actions so that women do not get as involved. In some extreme cases, some may even strictly separate women from their role before the changes. Such retrograde actions could weaken the community, and in the end they become less competitive and progressive in the near future. On small scaled community, it is true that women contribution is extremely important that without their existence, fishing activities and the life of the society could abruptly stop.

Some women are found to have important role starting from preproduction, production (tools used and fishing products), postharvest and sales and marketing (Fitriana and Stacey 2012). Evidently, women contributing activities took placed in Pantar, East Nusa Tenggara and has significant impact to the household's food security, and also to the income and other household needs in general. Some unidentified women are involved in the activities by using the very simple technology and tools, such as canoe to harvest and catching resources. They also play important role in processing or selling them. Thus, Coral Triangle Initiative (CTI) program of coral reefs conservation, fishery and food security by six countries (Indonesia, Malaysia, Papua New Guinea, The Philippines, Solomon islands, and Timor Leste), is a strategic sector to help alleviate poverty while improving the country's food security and protecting women's livelihood.

Women in the coastal villages are usually identified as the fisher's wife by the government. This means their contribution is not acknowledged as their own job, but as part of their household work in taking care of the family, which include reproduction, water, wood and food preparation, and house cleaning. Because of this classification, women working in the fishery is not counted in the national government census related to fishery in the district administration. Suppose that the Central Bureau of Statistic collect and produce data of fishery of each province, district and subdistrict on the total number of fishers (men) employed in the fishery sector, from full time, parttime or other minor part-time (for example, the statistic of Alor, East Nusa Tenggara where Kepulauan Pantar is).

Central Bureau of Statistic also classified fisherman based on time amount.(a) full time fisherman who works all day fishing; (b) part-time fisherman who works mostly in the sea, while having other work or activities; and (c) part-time fisherman (minor) who works in a short working hours. The information data also include tools and equipment used (such as the boat type, canoe, with or without motor), species harvested, and total amount of fish production.

On the other hand, Merry J. Williams in a book Why Look at Fisheries through a Gender Lens?, indicates an interesting research with respondents from Palau island, Philipines, in the north part of Indonesia, and Papua New Guinea (Williams 2008). This research propose the use of gender lens to observe fishery, so that the approach could reveal more information, and even more when combined with social context element. Merry's research result could find gender problem clearly from the age differentiation, role, responsibility, as well as opportunity and access from the fishery industry as a whole. Merry makes her point on the importance of an approach to solid and complete supply chain in the field for further fishery study, as well as important factor that produces good sell commodity. Fishery, study and aquaculture acts appreciate only the fish stock and production 
without gender lens. There is women fisherman, a word that directly related to role and knowledge. As a matter of fact, Merry also observe a case of HIV AIDS in Uganda island region, Africa

Palau women traditionally satisfied with the high social status, but it is now gone when the colonial power institutionalize the new governmental structure. Black (1984) describe how women and man in an isolated Tobi island of Palau break food production into parts, where women do the taro farming and man do the fishing in the sea. However, women also collected turtles in the coast and lagoon (Black 1984).

A three-month research in Palau found that women use 13 different fishing methods and they harvest many sea species. Two thirds women sell their fishing haul. Most of women fisherman comes from the beach and coastal area. Women's concern regarding environment and fish marketing, also decreasing resources is also explored in Merry's research. In 1999, this profession is upgraded by the Secretariate for Pacific Society (Lambeth 1999).

It was the time when most of women do the fishing, which rarely found in previous researches where most of women do the selling; the increasing competition of resources begun and the market infrastructure problems stayed unsolved. Thus, man and women needs on fishing should be protected and supported, as well as taking trainings on marketing and related skills. This research indicates that the government and non-governmental institution should come forward to handle it all. Conservation Institution such as Palau Conservation Society assisted by global and funding organization, focused on coral and coast resource program that allows women and children to be involved (Friedlander et al. 2017). These days, Secretariat for Pacific Society and Palau fishery agent take a look at all the previous fishery study in Palau coasts to have comprehensive and integrated assessment result on man and women society's involvement in the fish fishing, marketing and consumption. The studies affirmed that fishing done by three fourth households. Man, especially, put the haul as the target, but women shellfish is dominant in some islands in an ecosystem similar to reef peak. In general, the fishing results are put in an auction or market, and exchanged in the villages, and put on sale in the city market. Thus, small scale offshore fisheries give better household support than the income earned shown in numbers.

\section{Women Acknowledgment}

The facts mentioned show that not only as a helper for fisherman. Women have their own role, not to mention their involvement in the fishing activities. Their struggle to be acknowledged officially as fisherman in the identification card is very meaningful to them. It would create a great impact to women's life if they could obtain the status in their card amidst the patriarchy culture and man domination in the field (Febri et al. 2017). At the very least, they could have an access to health insurance, education and other rights guaranteed by the government.

In point of fact, what we can see today is that the women acknowledgment could actually be seen from how some women are going to the sea with their husband with the same sense of responsibility. When the fishers come along on the boat with their husband, the women often has bigger workload. Not only to prepare when to go the sea (sometimes include machine preparation and controlling the boat). Women has to throw water from the deck when in boat, preparing and spread the fishing net, separating fish from the net, carry the fish to the seller/market, sell the fish and clean the boat after. Prepare food while on boat is also part of women's work. When at home, they have to take care of house chores. Their husband, as a fisherman, has to prepare the boat, turn on the engine, control the boat, pull out the fishing net, separate fish from the net, bring the fish to the seller and clean the boat. In many areas, due to family economic demand, mothers in the coastal area become fishers. Not only to go to the sea, millions women are involved in almost all fishery chains in the country. People's Coalition Information Data Center for Fisheries Justice (Kiara) noted that there are 39 millions fishers are involved in the country's fishery production, starting from pre-production to post production. Quoted from Harian Kompas, General Secretary of Kiara, Susan Hermawati, stated that there are 12.827 coastal villages in Indonesia from the total of 78.609 villages throughout Indonesia, and at least 8.007.719 fishery households living in the coastal area 
and their lives depend on the fisheries activities. Women has great role, and their contribution to the family's economy could reach $48 \%$. On top of that, they reach the average of 17 hours as their working time. The country has approved to attach fisherman status for women in the Identification Card to 31 female fishers in Demak in 2017, and 28 fisherman women in Purworejo village in January 2018. This acknowledgment should be the first step to acknowledge women in fishery field in Indonesia.

\section{Conclusion}

Fisherman village in Jepara and Juwana Pati have significant sociological difference. At first, both villages are categorized as poor village. Juwana Pati is now an advanced and prosperous village. Fisherman of the village has now obtained status as rich and successful fisherman as boat seller village. No similar stories are found regarding Jepara village yet. Women status as fisherman has now slowly been acknowledged by the government, and has great impact to women amidst the patriarchy culture and man domination in the field. At the very least, they could have an access to health insurance, education and other rights guaranteed by the government.

\section{References}

Béné, C. 2003. "When Fishery Rhymes with Poverty: A First Step Beyond the Old Paradigm on Poverty in Small-Scale Fisheries." World Development 31, no. 6: 949-975.

Béné, C. and Friend, R. M. 2011. "Poverty in Small-Scale Fisheries: Old Issue, New Analysis." Progress in Development Studies 11, no. 4: 119-144.

Black, Peter. 1984. The Anthropology of Tobacco Use: Tobian Data and Theoretical Issues." Journal of Anthropological Research 40, no. 4: 475-503.

Febri, S. P. Eko S. Wiyono, Sugeng H. Wisudo, John Haluan, Gudhi H. Iskandar. 2017. "The role of women in small-scale fisheries of Langsa City, Aceh, Indonesia." Aquaculture Bioflux 10, no. 2: 402-409.

Fitriana, Ria and Natasha Stacey. 2012. "The Role of Women in the Fishery Sector of Pantar Island, Indonesia." Asian Fisheries Science Special Issue 25 S: 159-175. Accessed August 2, 2018. http://www.asianfisheriessociety.org/publication/pdf/0701738001355738288.pdf.

Friedlander, Alan M., Yimnang Golbuu, Enric Ballesteros, Jennifer E. Caselle, Marine Gouezo, Dawnette Olsudong, Enric Sala. 2017. "Size, Age, and Habitat Determine Effectiveness of Palau's Marine Protected Areas." PLoS One 12, no. 3: 1-18.

Mubyarto et al. 1984. Nelayan dan Kemiskinan, Studi Ekonomi Antropologi di Dua Desa Pantai. Jakarta:Rajawali.

Saktiya. 2016. "Desa Bendar, Desa Nelayan Terkaya di Juwana Pati." Accessed August 2, 2018, 2018. https://www.berita10.com/2016/03/desa-bendar-desa-nelayan-terkaya-di-juwana-pati/.

Suhardi. Without year of publication. Perkembangan Masyarakat Nelayan Desa Bendar Kecamatan Juwana Pati 1969-1983. Universitas Sebelas Maret, unpublished.

Triratnawati, A. 2012. Alang-alang, Potret Perempuan Manula pada Komunitas Nelayan Jawa. Yogyakarta: Balai Penelitian Nilai Tradisional Jawa Tengah.

Williams, Meryl J. 2008. "Why Look at Fisheries through a Gender Lens?," Development, Palgrave Macmillan; Society for International Deveopment, vol. 51(2), pages 180-185, June. 